\title{
Assessment of the effect of heterosis on semen parameters of two-breed crosses of Duroc, Hampshire and Pietrain boars
}

\author{
Anna Wysokińska and Stanisław Kondracki \\ Department of Animal Reproduction and Hygiene, Institute of Bioengineering and Animal Breeding, University of \\ Natural Sciences and Humanities, Siedlce, Poland
}

\begin{abstract}
The study was performed on 4609 ejaculates obtained from 32 boars, including 14 purebred and 18 two-breed crosses. The ejaculates were collected manually every 4-5 days. The study involved ejaculates collected from each boar from the first day of its insemination use until the day of semen depletion. Each ejaculate was assessed for the following physical parameters: ejaculate volume, sperm concentration, percentage of spermatozoa with correct motility, total sperm count per ejaculate and number of insemination doses obtained from one ejaculate. The effect of heterosis was calculated on the physical parameters of the boar crosses ejaculates in relation to the mean value of a given parameter for the parent breeds. Positive and well pronounced heterosis effects were identified in the majority of the physical ejaculate parameters of the cross boars for all the cross-breeding variants. A negative effect of heterosis was only identified in the ejaculate sperm concentration of the Hampshire $\times$ Pietrain crosses. The highest ejaculatory efficiency was identified in the hybrids produced on the basis of the Hampshire breed. These breeders were also found to feature significant heterosis effects on ejaculate volume, total ejaculate sperm count and number of insemination doses prepared from one ejaculate.
\end{abstract}

Keywords: heterosis, semen, boar hybrid

Archiv Tierzucht 56 (2013) 7, 65-74

doi: 10.7482/0003-9438-56-007

Corresponding author:

Anna Wysokińska; email: annaw@uph.edu.pl

Department of Animal Reproduction and Hygiene, University of Natural Sciences and Humanities, 08-110 Siedlce, Prusa 14, Poland

(c) 2013 by the authors; licensee Leibniz Institute for Farm Animal Biology (FBN), Dummerstorf, Germany. This is an Open Access article distributed under the terms and conditions of the Creative Commons Attribution 3.0 License (http://creativecommons.org/licenses/by/3.0/).
Received: 16 Dezember 2011 Accepted: 8 January 2013 Online: 22 February 2013 


\section{Introduction}

Cross-breeding is a method of using and adapting extraneous genes in a population that is being improved or in production herds in order to take advantage of inter-breed differences and heterosis for increasing hybrid productivity. Assessments of genetic effects on pig reproduction performance are useful when evaluating breed potential and devising efficient cross-breeding systems (Cassady et al. 2002). They also represent the prime method of increasing the economic efficiency of pig breeding (Nehring \& Staehr 2001, Gjurgji \& Sena 2009). Pig cross-breeding programs take advantage of the effect of individual as well as maternal and paternal heterosis. Heterosis is caused by a non-additive (non-summative) effect of genes and corresponds with higher efficiency of hybrids in comparison with the average efficiency of the parents. Hybrid efficiency is sometimes higher than the level attained by the better parent breed in a given parameter. The effect of heterosis may vary in intensity depending on the type of performance traits (Nwakpu \& Ugwu 2009). The effect of cross-breeding is generally more prominent in the case of low-heritable traits, i.e. those related with reproduction performance. In boars, the effect may appear in qualitative and quantitative semen characteristics. Two-breed crosses are readily used for reproduction, as they have intensive sexual urge and easily produce ejaculates, which is of particular importance for insemination. They are also generally tougher and more resistant than pure-bred boars (Czarnecki et al. 1999). Additionally, the semen of pure-bred boars is usually more vulnerable during transport and storage than hybrid semen (Sonderman \& Luebbe 2008). These observations show that ejaculates obtained from cross-bred boars have better quantitative and qualitative parameters as compared with ejaculates of pure-bred boars (Ciereszko et al. 2000, Maćkowski et al. 2004, Wysokińska \& Kondracki 2004, Kmieć et al. 2006, Terman et al. 2006, Wysokińska et al. 2006, Kawęcka et al. 2008). This suggests that they can be more economically and efficiently employed in insemination practice. As it turns out, however, not all cross-breeding variants are equally beneficial as regards qualitative ejaculate characteristics. The effect of cross-breeding largely depends on the accuracy of breed selection and appropriate cross-breeding practice. Hybrids usually provide high-quality ejaculates, as evidenced in the effect of heterosis, showing the advantage of crossbreds over pure-bred males (Smital et al. 2004, Wysokińska \& Kondracki 2004, Smital 2009, Wolf \& Smital 2009). Some hybrids also produce ejaculates whose parameters are less advantageous than those of the pure-bred animals (Falkenberg \& Ritter 1994, Wierzbicki et al. 2010) or intermediary in relation to the ejaculates of the pure-bred boars (Wysokińska et al. 2009).

The present work aimed at evaluating the effect of heterosis on semen parameters in twobreed boar hybrids derived from the Duroc, Hampshire and Pietrain breeds.

\section{Material and methods}

The study was performed on 4609 ejaculates obtained from 32 boars, including 14 purebred ones (4 Duroc, 5 Hampshire and 5 Pietrain boars) and 18 two-breed crosses (9 Duroc $\times$ Pietrain, 5 Hampshire $\times$ Pietrain and 4 Hampshire $\times$ Duroc boars [Table 1]). The ejaculates were collected manually (King \& Macpherson 1973) every 4-5 days. The study involved ejaculates 
collected from each boar from the first day of its insemination use until the day of semen depletion. Each ejaculate was assessed for the following physical parameters: ejaculate volume, sperm concentration, percentage of spermatozoa with correct motility, total sperm count per ejaculate, and number of insemination doses obtained from one ejaculate.

Table 1

Number of collected ejaculates

\begin{tabular}{lcc}
\hline Breed & Number of boars & Number of ejaculates \\
\hline Hampshire & 5 & 675 \\
Duroc & 4 & 582 \\
Pietrain & 5 & 1018 \\
Hampshire $\times$ Pietrain & 5 & 1330 \\
Hampshire $\times$ Duroc & 4 & 471 \\
Duroc $\times$ Pietrain & 9 & 533 \\
Total & 32 & 4609 \\
\hline
\end{tabular}

Following filtration of the gelatinous fraction, the ejaculate volume was determined on the basis of ejaculate weight measured with electronic scales. The sperm concentration in the ejaculates was determined with a photometric method using a spectrophotometer. The method consists in measuring the intensity of light passing through a suspension of spermatozoa in an isotonic solution of sodium chloride or sodium citrate. The percentage of adequately motile spermatozoa was determined microscopically. Using a zoom of approximately 200 -fold magnification, the percentage share of correctly motile spermatozoa in the total number of spermatozoa visible within the scope was determined. The total number of spermatozoa with correct motility and the number of insemination doses obtained from one ejaculate were calculated using SYSTEM SUL v. 6.35 (Gogosystem, Warsaw, Poland) computer program.

The results were statistically processed using analysis of variance according to the following mathematical model:

$$
Y_{i j}=\mu+a_{i}+e_{i j}
$$

where: $Y_{i j}$ is the trait value, $\mu$ is the population mean, $a_{i}$ is the boar breed effect and $e_{i j}$ is the error.

Significance of between-group differences was verified by means of Tukey's test at $P \leq 0.01$.

The effect of heterosis on the physical parameters of the boar hybrid ejaculates in relation to the mean value of a given parameter for the parent breeds was calculated as follows:

$$
V R=\frac{X_{F 1}-X_{M P}}{X_{M P}} \times 100
$$

where $V R$ is the effect of heterosis, $X_{F 1}$ is the mean value of a given parameter for the boar crosses, $X_{M P}$ is the mean value of a given parameter for the parent breeds. 


\section{Results}

Table 2 shows the effects of heterosis on the physical parameters of the ejaculates obtained from the Duroc $\times$ Pietrain hybrids, calculated relative to the mean value of the parameter for the Duroc and Pietrain breeds, respectively.

The identified effect of heterosis assumed positive values ranging from $0.49 \%$ for the percentage of progressively motile spermatozoa to $7.43 \%$ for the total ejaculate sperm count. The greatest advantage of the Duroc $\times$ Pietrain hybrids over the parent breeds was identified for the total ejaculate sperm count. The heterosis factor calculated for this parameter was the highest, at $7.43 \%$. The mean number of spermatozoa in the hybrid ejaculates was over $6 \mathrm{bn}$ higher than in the ejaculates of the Duroc and Pietrain pure-bred boars $(P \leq 0.01)$. The two-breed Duroc $\times$ Pietrain hybrid males revealed intermediary values for ejaculate sperm concentration and sperm motility as compared with the parent breeds, Duroc and Pietrain. The effect of heterosis on these parameters was positive. However, it did not exceed $1 \%$. The cross-breds produced over $30 \mathrm{ml}$ more voluminous ejaculates than the Duroc boars. On the other hand, the hybrid ejaculates had a $15 \mathrm{ml}$ lower volume than the Pietrain ejaculates $(P \leq 0.01)$. The ejaculates of the hybrids and pure-bred Pietrain boars served to prepare approximately 24 insemination doses, significantly more than in the case of the Duroc ejaculates $(P \leq 0.01)$.

Table 2

The effect of heterosis on the semen parameters of the Duroc $\times$ Pietrain hybrids in comparison with the mean value of the parameter for the parent pure-bred boars (VR)

\begin{tabular}{|c|c|c|c|c|}
\hline \multirow[t]{2}{*}{ Item } & \multicolumn{3}{|c|}{$\begin{array}{l}\text { Mean of the trait } \\
\text { (means } \pm S D)\end{array}$} & \multirow{2}{*}{$\begin{array}{c}\text { Heterosis } \\
\text { effect, \% } \\
\text { VR }\end{array}$} \\
\hline & Duroc $\times$ Pietrain & Duroc & Pietrain & \\
\hline $\begin{array}{l}\text { Number of } \\
\text { ejaculates }\end{array}$ & 533 & 582 & 1018 & \\
\hline $\begin{array}{l}\text { Ejaculate } \\
\text { volume, ml }\end{array}$ & $176.06^{A *} \pm 51.93$ & $145.87^{\mathrm{B}} \pm 44.78$ & $191.67^{\complement} \pm 57.10$ & 4.32 \\
\hline $\begin{array}{l}\text { Sperm concentration, } \\
\left.\times 10^{3} / \mathrm{mm}^{3}\right)\end{array}$ & $682.49^{A} \pm 196.65$ & $754.15^{\mathrm{B}} \pm 186.87$ & $600.13^{\complement} \pm 178.43$ & 0.79 \\
\hline $\begin{array}{l}\text { Percentage of spermatozoa } \\
\text { with correct motility, } \%\end{array}$ & $76.09^{A} \pm 5.07$ & $76.32^{\mathrm{A}} \pm 5.07$ & $75.12^{\mathrm{B}} \pm 5.61$ & 0.49 \\
\hline $\begin{array}{l}\text { Total sperm count per } \\
\left.\text { ejaculate, } \times 10^{9}\right)\end{array}$ & $89.81^{A} \pm 32.93$ & $83.80^{\mathrm{B}} \pm 33.22$ & $83.41^{B} \pm 28.52$ & 7.43 \\
\hline $\begin{array}{l}\text { Number of insemination } \\
\text { doses }\end{array}$ & $23.85^{\mathrm{A}} \pm 7.20$ & $22.69^{\mathrm{B}} \pm 7.74$ & $24.48^{\mathrm{A}} \pm 7.08$ & 1.15 \\
\hline
\end{tabular}

*Different superscripts mean significant differences among means within particular rows; upper-case letters: $P \leq 0.01$. 
Table 3 contains efficiency indices for the cross-breeding of the Hampshire and Pietrain boars relating to the physical parameters of the ejaculates collected from the hybrids. The data in Table 3 show a significant advantage of the Hampshire $\times$ Pietrain hybrids over the parent breeds in most of the semen parameters. A very high and positive heterosis effect was identified for ejaculate volume, total ejaculate sperm count and number of insemination doses obtained from an ejaculate. The two-breed hybrids were found to have over $70 \mathrm{ml}$ more voluminous ejaculates than the Hampshire boars and even over $110 \mathrm{ml}$ greater ejaculate volumes than the Pietrain boars $(P \leq 0.01)$. Additionally, the cross-bred boars had much better values of the total ejaculate sperm count and number of insemination doses than the parent breeds. The ejaculate sperm concentration of the Hampshire $\times$ Pietrain hybrids was more similar to that of the Hampshire boars, as opposed to the Pietrain males, which suggests a stronger influence of the Hampshire breed on the level of this parameter in the hybrids. The hybrid ejaculates were found to have a greater sperm concentration than the Hampshire ejaculates - roughly by 21 thousand $/ \mathrm{mm}^{3}$. On the other hand, the sperm concentration of the hybrid ejaculates was lower than that of the Pietrain boars by approximately 87 thousand/ $\mathrm{mm}^{3}(P \leq 0.01)$. The heterosis effect for this parameter was negative, at $-6.42 \%$.

Table 3

The effect of heterosis on the semen parameters of the Hampshire $\times$ Pietrain hybrids in comparison with the mean value of the parameter for the parent pure-bred boars (VR)

\begin{tabular}{lcccc}
\hline Item & $\begin{array}{c}\text { Mean of the trait } \\
\text { (means } \pm \text { SD) } \\
\text { Pietrain }\end{array}$ & Hampshire & Pietrain & VR \\
\hline $\begin{array}{l}\text { Number of } \\
\text { ejaculates }\end{array}$ & 1330 & 675 & 1018 & $\begin{array}{c}\text { Heterosis } \\
\text { effect, } \%\end{array}$ \\
$\begin{array}{l}\text { Ejaculate } \\
\text { volume, ml }\end{array}$ & $303.90^{\mathrm{A}} \pm 125.55$ & $229.24^{\mathrm{B}} \pm 80.80$ & $191.67^{\mathrm{C}} \pm 57.10$ & 44.40 \\
$\begin{array}{l}\text { Sperm concentration, } \\
\left.\times 10^{3} / \mathrm{mm}^{3}\right)\end{array}$ & $513.21^{\mathrm{A}} \pm 193.56$ & $492.24^{\mathrm{B}} \pm 136.72$ & $600.13^{\mathrm{C}} \pm 178.43$ & -6.42 \\
$\begin{array}{l}\text { Percentage of spermatozoa } \\
\text { with correct motility, } \%\end{array}$ & $74.43^{\mathrm{A}} \pm 4.98$ & $71.36^{\mathrm{B}} \pm 4.10$ & $75.12^{\mathrm{C}} \pm 5.61$ & 1.60 \\
$\begin{array}{l}\text { Total sperm count per } \\
\left.\text { ejaculate, } \times 10^{\circ}\right)\end{array}$ & $105.05^{\mathrm{A}} \pm 37.43$ & $77.66^{\mathrm{B}} \pm 27.02$ & $83.41^{\mathrm{C}} \pm 28.52$ & 30.45 \\
$\begin{array}{l}\text { Number of insemination } \\
\text { doses }\end{array}$ & $29.14^{\mathrm{A}} \pm 8.32$ & $23.02^{\mathrm{B}} \pm 6.97$ & $24.48^{\mathrm{C}} \pm 7.08$ & 22.69 \\
\hline
\end{tabular}

*Different superscripts mean significant differences among means within particular rows; upper-case letters: $P \leq 0.01$.

Table 4 shows a juxtaposition of the effect of heterosis on the semen parameters of the Hampshire $\times$ Duroc hybrids in relation to the mean value of this parameter for the parent breeds. The greatest advantage of the Hampshire $\times$ Duroc hybrids over the parent breeds 
was found for the total ejaculate sperm count and the number of insemination doses prepared from one ejaculate. The heterosis indices for these parameters were high, $36.11 \%$ and $24.90 \%$ respectively. Positive and significant heterosis effects were also identified for ejaculate volume and ejaculate sperm concentration.

Table 4

The effect of heterosis on the semen parameters of the Hampshire $\times$ Duroc hybrids in comparison with the mean value of the parameter for the parent pure-bred boars (VR)

\begin{tabular}{|c|c|c|c|c|}
\hline \multirow[t]{2}{*}{ Item } & \multicolumn{3}{|c|}{$\begin{array}{l}\text { Mean of the trait } \\
\quad(\text { means } \pm \text { SD) }\end{array}$} & \multirow{2}{*}{$\begin{array}{c}\text { Heterosis } \\
\text { effect, \% } \\
\text { VR }\end{array}$} \\
\hline & $\begin{array}{l}\text { Hampshire } \times \\
\text { Duroc }\end{array}$ & Hampshire & Duroc & \\
\hline $\begin{array}{l}\text { Number of } \\
\text { ejaculates }\end{array}$ & 471 & 675 & 582 & \\
\hline $\begin{array}{l}\text { Ejaculate } \\
\text { volume, } \mathrm{ml}\end{array}$ & $216.73^{A *} \pm 74.78$ & $229.24^{B} \pm 80.80$ & $145.87^{\complement} \pm 44.78$ & 15.56 \\
\hline $\begin{array}{l}\text { Sperm concentration, } \\
\left.\times 10^{3} / \mathrm{mm}^{3}\right)\end{array}$ & $675.64^{A} \pm 156.26$ & $492.24^{B} \pm 136.72$ & $754.15 \mathrm{C}$ & 8.42 \\
\hline $\begin{array}{l}\text { Percentage of spermatozoa } \\
\text { with correct motility, } \%\end{array}$ & $76.94^{\mathrm{A}} \pm 4.61$ & $71.36^{\mathrm{B}} \pm 4.10$ & $76.32^{\mathrm{C}} \pm 5.07$ & 4.20 \\
\hline $\begin{array}{l}\text { Total sperm count per } \\
\text { ejaculate, } \times 10^{9} \text { ) }\end{array}$ & $109.88^{A} \pm 40.04$ & $77.66^{\mathrm{B}} \pm 27.02$ & $83.80^{c} \pm 33.22$ & 36.11 \\
\hline $\begin{array}{l}\text { Number of insemination } \\
\text { doses }\end{array}$ & $28.54^{\mathrm{A}} \pm 8.46$ & $23.02^{\mathrm{B}} \pm 6.97$ & $22.69^{\mathrm{B}} \pm 7.74$ & 24.90 \\
\hline
\end{tabular}

*Different superscripts mean significant differences among means within particular rows; upper-case letters: $P \leq 0.01$.

Figure 1 shows the effects of heterosis on the ejaculate parameters of the hybrid boars produced in three cross-breeding variants, measured relative to the mean value of a given parameter for the parent breeds. Positive and well pronounced heterosis effects were identified in the majority of the physical ejaculate parameters of the hybrid boars for all the cross-breeding variants. A negative effect of heterosis was only identified in the ejaculate sperm concentration of the Hampshire $\times$ Pietrain hybrids. The highest ejaculatory efficiency was identified in the hybrids produced on the basis of the Hampshire breed. These breeders were also found to feature significant heterosis effects on ejaculate volume, total ejaculate sperm count and number of insemination doses prepared from one ejaculate. It seems, therefore, that the Hampshire breed may be particularly apt as a component in two-breed boar hybridisation. Hampshire pigs generally have a high meat content. They are, however, disadvantaged in having the RN-gene that deteriorates the processing value of meat. Therefore, it is more advantageous to use hybrids with a share of this blood, rather than pure-bred Hampshire males. 


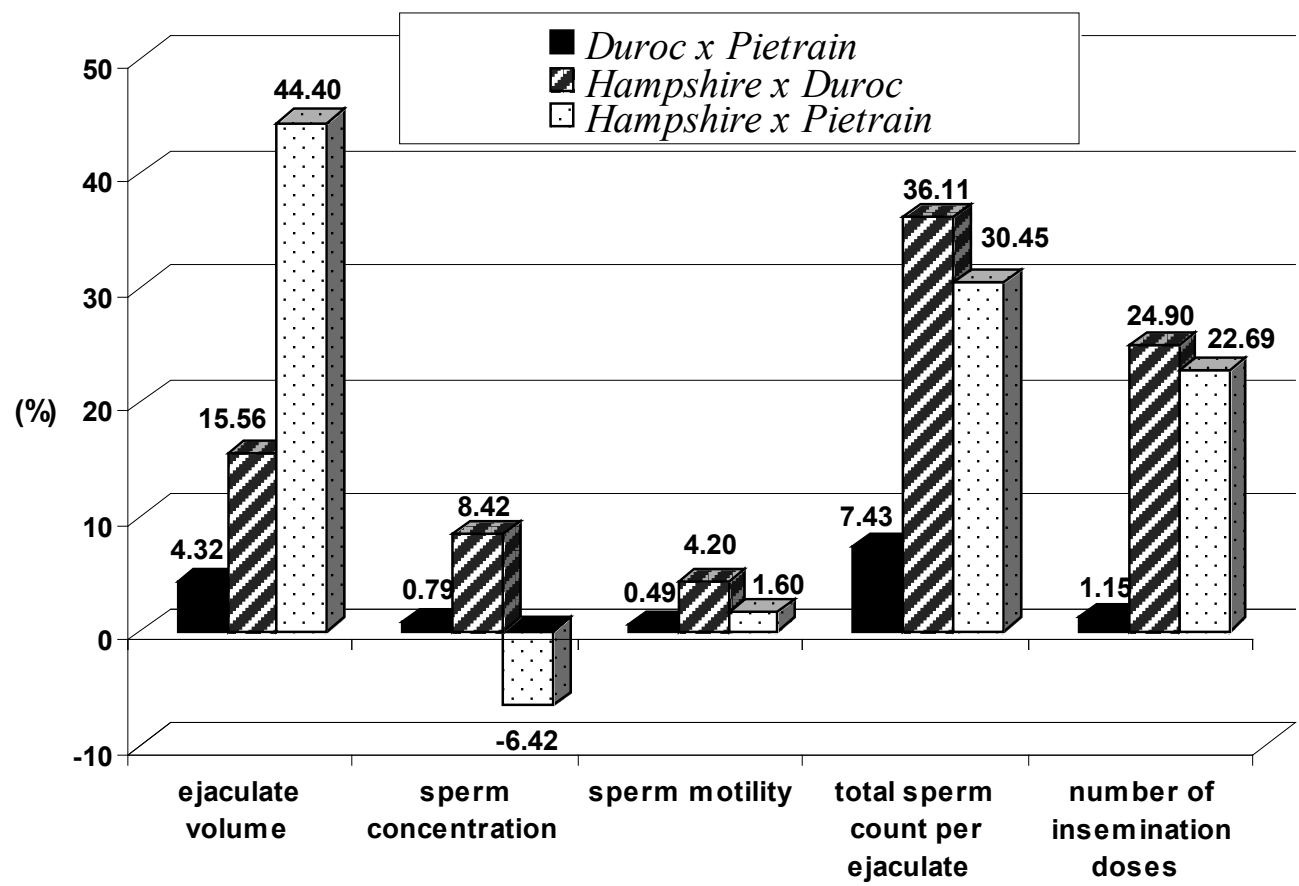

Figure 1

The effect of heterosis on the physical ejaculate parameters of the Duroc $\times$ Pietrain, Hampshire $\times$ Duroc and Hampshire $\times$ Pietrain hybrids

\section{Discussion}

The data presented in this study show that hybrids produced with the participation of the Hampshire breed provide ejaculates with the best quantitative and qualitative parameters. Such ejaculates usually contain the highest number of progressively motile spermatozoa. This characteristic is economically crucial, as it is used to determine the number of insemination doses prepared from an ejaculate. One ejaculate of the Hampshire $\times$ Duroc and Hampshire $\times$ Pietrain hybrids provided an average of roughly 29 insemination doses. The heterosis index for this parameter was high, over $22 \%$ for the hybrids in both the cross-breeding variants. $A$ study by Kondracki et al. (2006) shows that one ejaculate of two-breed Hampshire $\times$ Pietrain hybrids produces an average of over 5 insemination doses more than an ejaculate of Duroc $\times$ Pietrain or Hampshire $\times$ Duroc boars. The present study shows that Hampshire $\times$ Pietrain hybrids produce the most voluminous ejaculates, as evidenced in the heterosis effect on ejaculate volume, amounting to $44.4 \%$. Knecht et al. (2004) also identified the greatest ejaculate volume in Hampshire $\times$ Pietrain hybrids. These crosses, as well as Duroc $\times$ Pietrain breeders, were additionally found to be the most efficacious in insemination.

Two-breed Duroc $\times$ Pietrain crosses usually produce ejaculates of better quality, i.e. with better sperm motility and a higher total sperm count than pure-bred Duroc and Pietrain boars (Kawęcka et al. 2008). Different results were obtained by Wierzbicki et al. (2010). The researchers found that pure-bred Duroc, Hampshire and Pietrain breeders had 
greater ejaculate volumes and total ejaculate sperm counts than hybrid boars. Additionally, ejaculates of pure-bred males, especially those of Duroc boars, contained spermatozoa with better mobility in comparison with ejaculates of hybrid boars. The present study showed high sperm motility in hybrid boars derived from the Duroc breed as well as in pure-bred Duroc males. Sperm motility is a very important sperm parameter that reflects sperm quality and has a significant effect on egg cell fertilisation. A positive correlation was found between sperm motility and the number of piglets delivered at birth (Falkenberg \& Ritter 1994, Popwell \& Flowers 2000, Gadea et al. 2004, Ruiz-Sanchez et al. 2006, Vyt et al. 2008). Wysokińska \& Kondracki 2004 and Kondracki et al. 2003, 2006 and found the percentage of progressively motile spermatozoa in the semen of hybrids to be considerably higher than in the semen of pure-bred boars.

Sonderman \& Luebbe (2008), who analysed Duroc $\times$ Hampshire crosses and pure-bred boars, found that cross-bred boars were tougher and more resistant to diseases than purebred boars. That is why hybrid boars are used longer and their ejaculatory performance is better. According to the above authors, this fact may be somewhat misleading, causing the impression that the hybrids produce more ejaculates than Duroc boars, whereas in fact it is the difference in the period of utilisation that is crucial for ejaculatory efficiency.

The present study identified a positive influence of cross-breeding on the ejaculate parameters of the two-breed boar crosses, as evidenced in the analysed heterosis effects. Positive and very prominent effects of heterosis were determined for the most important ejaculate parameters in the case of all the analysed cross-breeding variants. There are few studies available that present heterosis indices for semen parameters. Smital et al. (2004) found positive and prominent effects of heterosis in Hampshire $\times$ Pietrain crosses on ejaculate volume $(30.6 \%)$ and ejaculate sperm count $(18.24 \%)$. Significantly lower but still positive heterosis effects were identified in Duroc $\times$ Pietrain hybrids. Slightly different observations were made by Czarnecki et al. (1999) as to the effect of Duroc and Pietrain cross-breeding. The scientists identified a positive effect of heterosis on ejaculate volume and a negative heterosis effect on the total ejaculate sperm count $(-12.72 \%)$. The results of the present study show that Duroc $\times$ Pietrain hybrids produce ejaculates with intermediary values of most of the physical ejaculate parameters in comparison with pure-bred Duroc and Pietrain boars. This is evidenced in the modest, though positive, effects of heterosis. Ejaculates of Duroc boars usually produce fewer insemination doses than ejaculates of other breeds. This is connected with the predisposition of Duroc boars to produce ejaculates with low volumes and high sperm concentration, as confirmed by results of numerous studies (Leidinger et al. 1998, Park \& Yi 2002, Kondracki 2003, Smital et al. 2004, Kondracki et al. 2011). Therefore, it is more advantageous to use two-breed reproduction males derived from the Duroc breed, rather than pure-bred Duroc boars.

Summing up, it has to be stated that the heterosis indices revealed a clear advantage of the crossing boars over the pure-bred reproduction males in the case of the most important semen parameters. The greatest advantage of the hybrids over the parent-breed boars was observed for the ejaculates collected from the hybrids derived from the Hampshire breed. The Hampshire $\times$ Pietrain and Hampshire $\times$ Duroc hybrids displayed high and positive effects of heterosis on ejaculate volume, total ejaculate sperm count and number of insemination doses prepared from one ejaculate. 


\section{References}

Cassady JP, Young LD, Leymaster KA (2002) Heterosis and recombination effects on pig reproductive traits. J Anim Sci 80, 2303-2315

Ciereszko A, Ottobre JS, Glogowski J (2000) Effects of season and breed on sperm acrosin activity and semen quality of boars. Anim Reprod Sci 64, 89-96

Czarnecki R, Różycki M, Udała J, Kawęcka M, Kamyczek M, Pietruszka A, Delikator B (1999) [The growth rate, meatiness value and reproductive performance of young Duroc boars and their hybrids with the Pietrain breed]. Rocz Nauk Zoot (Suppl.), 105-110 [in Polish]

Falkenberg H, Ritter E (1994) [Relations between morphological and biochemical sperm characteristics in boars and farrowing performance in sows]. Arch Tierz 37, 287-300 [in German]

Gadea J, Sellés E, Marco MA (2004) The Predictive Value of Porcine Seminal Parameters on Fertility Outcome under Commercial Conditions. Reprod Domest Anim 39, 303-308

Gjurgji F, Sena L (2009) Evaluation of genetic parameters on crossing in pigs bred. Biotech Anim Husb 25, 811-816

Kawęcka M, Pietruszka A, Jacyno E, Czarnecki R, Kamyczek M (2008) Quality of semen of young boars of the breeds Pietrain and Duroc and their reciprocal crosses. Arch Tierz 51, $42-54$

King GJ, Macpherson JW (1973) A Comparison of Two Methods for Boar Semen Collection. J Anim Sci 36, 563565

Kmieć M, Terman A, Wojdak-Maksymiec K, Romaniuk K (2006) Semen characters in reproductive Al boars depending on polymorphism in steroid 21-hydroxylase gene. Arch Tierz 49, Special Issue, 337-344

Knecht D, Jasek S, Procak A, Krzyżewski P (2004) Efficiency of inseminating sows with pure breed and crossbreed boars. Medycyna Wet 60, 1208-1211

Kondracki S (2003) Breed differences in semen characteristics of boars used in artificial insemination in Poland. Pig News Info 24, 119-122

Kondracki S, Wysokińska A, Kowalczyk Z (2003) [The effect of crossing of Duroc and Pietrain breeds on semen quality of crossbred boars]. Zesz Nauk Prz Hod 68 (2), 105-112 [in Polish]

Kondracki S, Wysokińska A, Banaszewska D, Zajda J (2006) Breed-related variation in ejaculate traits of Al boars. Anim Sci Pap Rep 24 (3), 121-129

Kondracki S, Wysokińska A, Iwanina M, Banaszewska D, Sitarz D (2011) Effect of sperm concentration in an ejaculate on morphometric traits of spermatozoa of Duroc boars. Pol J Vet Sci 14, 35-40

Leidinger H, Reiner G, Krapoth I, Dzapo V (1998) [Relations between spermatozoa volume and fertility in boars]. Arch Tierz 41, 65-73 [in German]

Maćkowski M, Świtoński M, Maćkowska J, Perz W (2004) Polymorphism of the GPX-5 gene and characteristics of boar semen. Arch Tierz 47, 165-171

Nehring H, Staehr B (2001) Efficient use of bulls and boars for Al. Arch Tierz 44, Special Issue, 121-133

Nwakpu PE, Ugwu SOC (2009) Heterosis for litter traits in native by exotic inbred pig crosses. J Trop Agric Food Env Ext 8, 31-37

Park CS, Yi YJ (2002) Comparison of semen characteristics, sperm freezability and testosterone concentration between Duroc and Yorkshire boars during seasons. Anim Reprod Sci 73, 53-61

Popwell JM, Flowers WL (2004) Variability in relationships between semen quality and estimates of in vivo and in vitro fertility in boars. Anim Reprod Sci 81, 97-113

Ruiz-Sánchez AL, O'Donoghue R, Novak S, Dyck MK, Cosgrove JR, Dixon WT, Foxcroft GR (2006) The predictive value of routine semen evaluation and IVF technology for determining relative boar fertility. Theriogenology 66, 736-748

Smital J, De Sousa LL, Mohsen A (2004) Differences among breeds and manifestation of heterosis in Al boar sperm output. Anim Reprod Sci 80, 121-130

Smital J (2009) Effects influencing boar semen. Anim Reprod Sci 110, 335-346 
Sonderman JP, Luebbe JJ (2008) Semen production and fertility issues related to differences in genetic lines of boars. Theriogenology 70, 1380-1383

Terman A, Kmieć M, Polasik D (2006) Estrogen receptor gene (ESR) and semen characteristics of boars. Arch Tierz 49, 71-76

Vyt P, Maes D, Quinten C, Rijsselaere T, Deley W, Aarts M, de Kruif A, Van Soom A (2008) Detailed motility evaluation of boar semen and its predictive value for reproductive performance in sows. Vlaams Diergeneeskundig Tijdschrift 77, 291-298

Wierzbicki H, Górska I, Macierzyńska A, Kmieć M (2010) Variability of semen traits of boars used in artificial insemination. Medycyna Wet 66 (11), 765-769

Wolf J, Smital J (2009) Quantification of factors affecting semen traits in artifical insemination boars from animal model analyses. J Anim Sci 87, 1620-1627

Wysokińska A, Kondracki S (2004) Heterosis effects on physical traits of ejaculate in Duroc $\times$ Pietrain and Hampshire $\times$ Pietrain crossbred boars. Anim Sci Pap Rep 22, 595-601

Wysokińska A, Kondracki S, Banaszewska D (2006) Application of spermiogram classification in the evaluation of the semen morphology of Duroc $\times$ Pietrain crossbreeds and purebred Duroc and Pietrain. Anim Sci Pap Rep 24 (Suppl. 3), 319-325

Wysokińska A, Kondracki S, Kowalewski D, Adamiak A, Muczyńska E (2009) Effect of seasonal factors on the ejaculate properties of crossbred Duroc $\times$ Pietrain and Pietrain $\times$ Duroc boars as well as purebred Duroc and Pietrain boars. Bull Vet Inst Pulawy 53, 677-685 